\title{
Sang-tarash: the Legendry Master Sculptors of the Ancient Buddhist Sculptural Art of Gandhara in Taxila
}

\author{
Shabnam Bahar Malik Ph.D \\ Director, Research and Development, Bahria University, Islamabad \\ Shangrila Road, E-8, Islamabad, Pakistan \\ Tel: 92-51-926-3419 E-mail: drd@bahria.edu.pk
}

Received: April 15, $2011 \quad$ Accepted: June 3, $2011 \quad$ Published: October 1, 2011

doi:10.5539/ass.v7n10p195

URL: http://dx.doi.org/10.5539/ass.v7n10p195

\begin{abstract}
The main objective of this paper is to get various stakeholders acquainted with the immaculate work of [re] production of Buddhist Sculptural Art of Gandhara in Taxila, by master sculptor [s] using genuine stones and centuries old techniques. The paper reviews the [re] production process as practiced at present by the master sculptors in their workshops. The article analyses the major obstacles in open marketing of these exquisite pieces of Buddhist stone art. The findings are based on ethnographic fieldwork and in-depth interviews of master sculptor [s] in Taxila, in particular in village Pathrian (pseudonym). Current analysis is carried out in the backdrop of various socio-religious and legal impediments obstructing the promotion and very survival of this ancient art form. Based on findings the study proposes some viable solutions to preserve and promote this dying art from total extinction.
\end{abstract}

Keywords: Buddhist, Stone art, Gandhara, Taxila, Master sculptors, Preservation

\section{Historical Background}

Gandhara is the name of an ancient kingdom (Mahajanapada) which was located in Northern Pakistan and Eastern Afghanistan. The kingdom lasted from early $1^{\text {st }}$ millennium BC to the $11^{\text {th }}$ Century A.D. Its main cities were Purushapura (modern Peshawar), Pushkalawati (modern Charsadda), Takshasila (modern Taxila), and Mathura (in India). In Gandhara Mahayana Buddhism flourished from middle of the $3^{\text {rd }}$ century BC and Buddha was represented in human form (Khan \& Hasan, 2003). It attained its golden age from $1^{\text {st }}$ century to $5^{\text {th }}$ century A.D. under Buddhist Kushan Kings. Under the rule of great Kushan King Kanishka (128-151) Gandhara became a Holy land of Buddhism and huge statues of Buddha were erected in mountains and carved into the hillsides. This attracted Chinese pilgrims like Faxian (Fa-hsien), Songyun (Sung-yun) and the famous Xuanzang (Hsuan-tsang) to see the monuments associated with various Jataka (birth) tales. In $5^{\text {th }}$ century A.D. White Huns attacked and destroyed the Buddhist monasteries of Taxila and as noted by Khan and Hasan, "The great trauma that Buddhism and the Buddhsit art of Gandhara received is difficult to imagine. After this great catastrophe, Buddhism rapidly disappeared from its second homeland and the Buddhist art lost the great patrons," (Khan and Hasan, 2003). While talking about the particular genre of Gandhara art, Ahmed notes, that the art declined after $6^{\text {th }}$ century due to various reasons including; invasion of White Huns (in $5^{\text {th }}$ century AD) lack of patronage, the revival of Hinduism and "the emerging trend of using stucco and terracotta instead of schist for sculpturing," (Ahmed, 2010).

\section{Introduction to Historical Taxila and its Stone Art}

About 32 kilometers northwest of the Capital City of Islamabad, the ancient Gandharan city of Takshasila [Taxila] harbors one of the best Buddhist archaeological sites in the world. In 1980 Taxila was declared a UNESCO World Heritage Site. See Figures 1 and 2.

It attracts tourists from across the globe throughout the year, especially from the Buddhist countries. The valley of Taxila is also home to the centuries old Buddhist stone art of Gandhara and abode to the legendry master sculptors. By sculpting beautiful statues of Buddha and reliefs of jataka tales these sculptors have kept this ancient art alive to the present day under various socio-religious and legal impediments. 
In Taxila sculptures of Buddha are produced using two totally different techniques. The first is through using molds, in cement, stucco, terracotta and plaster of Paris, the second technique (the title of this paper) is by carving sculptures of Buddha using genuine stones of particular type [s]. The two techniques of producing the statues and life-imagery of Buddha are a gulf apart in terms of skill, materials used and price range. The master sculptors of Taxila work on these exquisite pieces of art against various socio-economic and legal threats, especially the growing religious extremism in the region lately, and hence, needed some serious investigation.

The promotion and preservation of this ancient Buddhist stone art of Gandhara is in dire need of patronage for its survival from a total extinction. May be in the same way the Italians have done to save epigraphical records in the Gilgit-Baltistan region (formerly Northern Areas) of Pakistan, by producing their replicas (Khalid, 2011). Although, genuine stone reliefs of jataka tales and other souvenirs are also produced by the master sculptors, present study only focuses on the production of statues of Buddha, called mjasma or moorti, a generic term used for a statue locally. The statues are intricately carved and finished using genuine stones of various types and hand tools by master sculptors in Taxila, (Note 1) known as sang-tarash, meaning stone carvers, in the local parlance

The findings are based on my three years of visitation and ongoing research on Buddhist stone art of Gandhara in Taxila area and interviews with local artisans, stone carvers and master sculptors. The main findings, however, are based on a particular case study of a master sculptor, Sahil Khan and artisans working at his workshop in village Pathrian (pseudonyms) in Taxila, see Figure 3.

In-depth interviews of the master sculptor and his team of stone carvers who do the cutting, decorating and finishing of the sculptures under the tutelage of their teacher (ustad), using genuine stone [s] and applying various hand tools and techniques, as discussed in the subsequent text. There are other in-house workshops as one travels along the main Museum Road to the archaeological sites but they also operate secretly due to an ever evident fear of a raid by the concerned authorities.

\section{Problem Areas in Promotion of Buddhist Gandhara Sculpture}

The centuries old Buddhist stone art of Gandhara in Taxila is currently slowly dying out under immense pressure from various socio-economic legal and religious impediments. The Islamic ideology that prohibits the making of idols (but) and using them as a source of income does not fit into the local rationale of earning a livelihood in a Muslim society. Those who make these statues are generally cursed by their own families as well as neighbors people. Due to a fear of rejection those who know the craft of sculpting many times stay away from publically making and selling their craft and generally work in hiding due to expected threats from local clergy demanding to stop the production of idols.

The legal restrictions to produce genuine stone sculptures of Buddha under the Antiquity Laws of 1975, and Antiquities Export Control Act of 1947 (Section 3), and The Customs Act, 1969, also hinder the promotion and open marketing of this art locally and export to international markets. The genuine stone statues, especially using stones that were used in antique stone sculptures, for instance green schist stone, (Marshall 1960, Aman 2004) is legally prohibited.

A recent Dawn news brief talked about the problems faced by the Department of Archaeology and Museums (DOAM) and notes quoting an official of DOAM that, "With illegal digging still a menace, smuggling of archaeological treasures is almost impossible to stop," he further notes that "DOAM lacks an enforcement machinery to lessen if not completely stop such incidents," (Shahid 2011, Zaman 2011).

A talk with Director General Archaeology and Museums, in 2009, revealed that the restriction on genuine stone replicas is enforced to avoid smuggling of genuine antiquities of Buddhist art. According to his justification, it is primarily done to stop trafficking in genuine Buddhist statues. In the guise of replicas local traders and smugglers many times sell antique pieces (personal communication with Director General, DOAM, Islamabad). He informed that producers can sell under license legally, but no one from Taxila ever asked his office for a license! Something hard to believe!

The argument of the department of Archaeology and Museums did not seem to be carrying much weight. The statement was denied by the producers and instead they complained that DOAM never issues a license even if contacted. Marketing can be improved manyfold if the department of archaeology and museums starts issuing licenses, as per 1947 Antiquities Export Control Act, providing reproduction certificate [s] or by printing reproduction at the bottom of a piece to discourage trafficking of antique pieces. A practice also observed in the Western countries like for instance in Canada, where at Royal Ontario Museum (ROM) reproductions of antique 
pieces are sold on a proper Museum Reproduction Shop, with details printed on accompanying product history paper accompanying each sold item.

\subsection{Traffic in Buddhist Antiquities and the Role of Regulatory Authorities}

There are three major Acts which effect the antiquities trade in Pakistan. These include:

\subsubsection{Antiquities Act 1975, under sections 24}

Section 24 reads, " Penalty for counterfeiting etc., of antiquity: (1) whoever counterfeits, or commits forgery in respect of any antiquity with intent to commit fraud or knowing it to be likely that fraud will thereby be committed, or cause anything to appear like, or to be believed to be, and antiquity with intent to cause wrongful gain to one person or wrongful loss to another person, shall be punished with imprisonment for a term which may extend to six months or with fine, or with both," (Antiquity Act 1975, 1992:17).

3.1.2 Customs Act 1969, under sections 15-16 and 17

\subsubsection{Antiquities Export Control Act 1947, under Section 3}

Under section 3, it reads "No person shall export any antiquity except under the authority of a license by the Central Government," (Antiquities Export Control Act, 1947).

\subsubsection{International Conventions regarding Protection of Cultural Property}

"The 1972 UNESCO Convention concerning the Protection of the World Cultural and Natural Heritage was established to safeguard cultural and natural heritage of outstanding universal value for future generations" ("World Heritage Reports,[12]" 2004). Pakistan is one of the 177 states that adopted and ratified the convention in 1976.

In spite of having multiple Acts the traffic in Buddhist antiquities is going on both in Pakistan and lately in neighboring Afghanistan. In a special report in Archaeology Magazine (2002) two reports, "Plundering Afghanistan" by Ansari and "Challenges in Pakistan" by Kenoyer, pointed toward traffic in antiquities in Pakistan and Afghanistan. Ansari in his report notes, "Despite the fact that Pakistan's 1975 Antiquities Act states that anything older than 75 years be neither sold nor purchased for commercial purposes, artifacts from Afghanistan and even Pakistan itself are sold openly throughout the country." More importantly he notes, "Although the Antiquities Act punishes smugglers with five to 20 years of imprisonment, not a single person to date has been prosecuted under the act, even though several gangs of antiquities smugglers have been apprehended." Talking about the role of local authorities in this antiquities smuggling he notes "local authorities are often indifferent to the illegal trade, and even when a case reaches the country's notoriously slow court system, wealthy smugglers and dealers use their cash and contacts to have charges dropped," (Ansari, 2002). The major favored hunting grounds for antiquities dealers and trade spots identified by him include, the sprawling Afghan refugee camps of Jalozai and Shamshatoon, near Peshawar, and a colossal refugee settlement near Chaman, in Baluchistan Province. Here, he notes, " they buy thousand-year-old statuettes and jewelry, as well as centuries-old copper and bronze pots, and musical instruments from displaced Afghans for a pittance. Dealers regularly troll the camps for treasures at throwaway prices, and often place orders with refugees returning to Afghanistan," (Ansari, 2002).

Kenoyer, on the other hand, pointing to the particular situation of Pakistan in his report, states "Archaeologists have to be proactive in many different ways. There is nothing I can do to stop this war, but I do want to save history and help people understand their past...I also point out that one of the most important things distinguishing people from animals is a concept of history and culture. When we lose that, we lose our human identity and become animals," (Kenoyer, 2002).

To the relief of many Buddhist art lovers, recently the wife of the South Korean ambassador to Pakistan, Choi In-Sun said in her visit to the proposed site near Dharmarajika Buddhist site, that "South Korea is keen to support the Gandhara renaissance project in Taxila to revive the 2500 years old Buddhist University of Taxila with feature of the $21^{\text {st }}$ century," (Correspondent, 2010).

During my three years of experience working on pieces of Buddhist stone art reproductions in Taxila, I have read countless articles on trafficking of antiquities reported by the media and the local newspapers. All those reports could not convince me that [re] production of the exquisite pieces of Buddhist sculptural art should be left to an evident slow death due to these trafficking incidents and the forthcoming case study of a master sculptor-cum-dealer from Taxila, is an effort in this direction to try to analyze the real situation and propose some measures to promote and to save the vulnerable Buddhist stone art heritage of Gandhar in Taxila. 


\section{Case Study: Master Sculptor, Ustad Sahil Khan}

Sahil Khan (pseudonym), a master sculptor in village Pathrian, is one of those few prominent master sculptors called ustad (teacher) left behind who have established their workshops and working against all odds to produce some of the most unique pieces of Buddhist stone art in this area for the local as well as international markets and in helping to keeping this art alive.

The subsequent text is an elaborate account of how the Buddha sculptures are produced and materials and techniques used by Sahil Khan in his workshop. How the clandestine marketing is managed by him and who are the buyers of his statues? How he manages with various day to day problems and how he views the problems identified by various stakeholders in this precarious business.

\subsection{Stones used in Sculpture Making and the Price Range}

According to Sahil Khan, the green schist stone and the black stone called Gandhara stone that he uses for his sculptures is only available in Malakand, in Swat. Most antique Buddha sculptures, as per Sahil, are only produced in these two stones and colors, see Figures 5, 7, 8, 9, 13 and 14, depicting pieces made with these stones. Both are soft stones and easy for carving. Another stone that he occasionally uses is what is called as Margalla stone, as it is brought on a small scale from nearby Margalla Hills.

One truckload of black stone or green schist stone, used primarily for producing statues of Buddha, cost rupees 60 to 70000 . Whereas only 16 to 17 big pieces of stone is what a truckload can carry. Many of these stone-slabs are thick enough to carve a statue but at times some defected pieces that are useless for sculpting also become part of the truckload

As per his experience, the schist stone from a deeper dig that has some moisture in it is the best for sculpture making as it is soft and has no cracks. The upper layer of a rock is generally dry and can have cracks, in which case the slabs become useless and can not be used for carving. Due to this problem it involves an experienced eye to even select a proper stone quality for producing the desired quality of carved pieces. Even during the carving process the half made pieces are soaked into water tanks to soften them for further finishing, see Figure 10. Sahil Khan informed, he goes himself many times but there are times he has to order stone through contractors, who deliver the stone at his workshop in village Pathrian, See Figure 3.

He earlier had a workshop elsewhere in Taxila, but had recently moved to his present three-room workshop in village Pathrian, See Figure 4. The village is also locally called sangtrashon-ka-sheher, or the city of stone-carvers, due to the high incidence of stone-carvers and stone-cutters residing and working from this village.

\subsection{Sculptors and Artisans}

On the day of our visit there were four stone carvers working on various sculptures of Buddha and a relief, see Figures 5, 6 and 12. According to Khan, he does not pay them any daily wage, but if they produce a piece of their own, he helps them in marketing the piece. (Note 2) The marketing is the most tricky part once a piece is ready, owing to no local customers and international dealers are not in the approach of an average artisan working in his workshop, so he also serves as a middleman to market any pieces produced by any of his worker in the workshop.

\subsection{International Marketing of Buddha Sculptures from Taxila}

According to Sahil Khan the statues are marketed to Italy, Japan, France, London, Korea, America, Switzerland and Sri Lanka by him. Thailand (Bangkok) is also an international outlet for statues for local smugglers to fetch high prices.

He told, he only has contact with six dealers locally who are his major permanent source for marketing his finished pieces. They regularly come and buy from him and sell the pieces in the international market on much higher prices, especially Bangkok is a big market for the Buddhist statues. He was not happy due to the middleman taking the advantage of selling on a much higher price, due to having no international marketing linkages, and desired that concerned departments should help the artists to export directly to the original buyer [s].

\subsection{Styles of Sculptures Sahil Khan Specializes}

According to Sahil Khan, he has worked in both Gandhara and Mathura or Hindu Shahai style, as he calls it. He said Mathura is much more difficult as the stone that is used is much harder than the Gandhara stone. He also over the years worked in gold and silver for custom made pieces for his wealthy local clients (some well known industrialist families). 


\subsection{No Support from Government}

He was very critical of Department of Archaeology and Museums and accused them of smuggling antiquities themselves and not letting locals get any benefit out of selling either antiquities or stone replicas of Buddhist art. According to him if a local discovers a site (which are numerous in this area) they come and raid and confiscate the relics and give a statement that the site was discovered by them. He quoted the example of a site "Jinna Wali Dheri" which was discovered by him and some other locals and was taken over by the DOAM, who later stated it was their discovery to the media. Such injustices, he said, are so common in the absence of any effectiveness of the regulatory authorities. This clearly shows the strife between the local producers and the DOAM. A better communication and liaison between the two can have a positive impact on both production and marketing of Buddhist art.

\subsection{Local Production of Cheap replicas}

He also blamed the producers of cheap replicas, which are produced using molding technique, (Note 3) as responsible for his declining business. He said if people can buy a piece for one hundred to few hundred rupees, why would they buy a genuine stone replica paying rupees 10,000, for instance for the piece shown in front in Figure 14. Similarly the genuine stone stupa in this visual will also cost almost an equal amount. There is huge price difference between the two, the quality is much superior, but why would a casual visitor or tourist care to pay so much money for the lookalikes, is the real question?

\subsection{Calculation of Selling Price}

According to Sahil Khan, sculptures of Buddha are especially made for particular clients on order, from rupees 25000 to rupees 30000 per foot. But also negotiation depends on who is the buyer. For a wealthy customer we make fine pieces whereas an average buyer only gets an average quality statue. The more someone pays the more refined piece he would get. According to him from looking at a piece sometimes one can tell who has made it, as per his claim his clients only want him to make a piece for them as his finishing technique is so perfect. Final touches to the face are especially important and that's where an average piece can be distinguished from a piece made by a master sculptor, as himself. The buyers are very savvy and know the difference, and ready to pay the price for a fine piece.

\subsection{Local Producers and Traffic in Buddhist Antiquities}

Sahil Khan shared a particular incident where once travelling with two other partners to Peshawar City carrying some antique Buddhist art pieces, they were raided by the customs department and arrested. The pieces they were carrying were confiscated. They were jailed for 100 days, but that was the only incident he ever came across. They were arrested in 1990 and in 1999 the court gave the final verdict on the case and during all these years they kept visiting courts for litigation. Also, that locals try to smuggle genuine pieces with the help of outsiders, who are part of trafficking mafia, from all surrounding areas as Taxila valley is enriched with Buddhist antiquities. Many bounty hunters are spotted and arrested, others just get by. Many belong to the law enforcing agencies themselves, complained Sahil, including the department of Archaeology and Museums.

\subsection{Training Time}

According to him, how long it takes to train a person all depends on the person. Those who can easily make use of hammer and chisel (chirri) the two major tools used can be fine. If an intern can not even do this much then he can not learn this trade and is abandoned by him. See Figures 11 and 12, showing chirri and other tools for carving. See Aman for a detailed description of carving tools and techniques for Buddhist sculptures made in Taxila (Aman, 2004).

His two brothers were also part of his team of four workers present on the day of the visit. He said my brother first used to say I do not want to make "but" but now he is started learning it with me because he does not find any other source of livelihood for him and for his family. The down side of this situation is that if people in this area found another job they will leave crafting statues, and the obvious outcome will be that stone sculptors will disappear from this area and so will be their ancient art.

\subsection{Making of a Sculpture (mjasma)}

One of the workers showed us how he traces designs for jewelry on stone, see Figure 16. His only simple tools were a compass called phulkar and a regular ink marker in blue color. The stone he was demonstrating was from a place called Serikot, also known as Serikot Stone, very famous for carving on head stones of graves in village of Serikot near Taxila. He uses the same technique for tracing jewelry on the schist stone for Buddha sculptures. The artists use books with enlarged drawings of Buddha and copy details of a particular sculpture from there. 
Also, they use Sir John Marshall's book (Marshall, 1960) for taking help in shaping various types of Buddha sculptures.

According to a workshop artisan, Masum, who carves jewelry on statues, at least three people work on various stages on a sculpture or mjasma. The first one takes out the simple shape or body of the statue, see Figures 8 and 11 , the second person does the jewelry work and the third generally the master sculptor does the face and the final touches. The third and last part involves the most intricate carving work and requires an expert hand of experienced master sculptor. A difficult and time consuming job that determines weather a piece will fetch a good price or not. A savvy buyer can easily differentiate if the face and shape is worked out by a master sculptor or not.

Usually for basic work a layperson is hired on daily wages or a lump sum payment. The real stone carvers are hard to find. Sahil Khan told only ten to fifteen people can be termed as master sculptors in the whole Taxila area.

Sahil urged that the concerned authorities should let local artisans make stone art and market it after fulfilling the legal requirement of selling under a license. Such initiative will give a boost to local economy and an opportunity to impoverished artisans to make an income. (Note 4) Concerned authorities create more hurdles for local artists rather than promoting or facilitating this dying art. If one can not make a living out of this work, as is the situation right now, then the new generation would not want to learn this hard job for a living. He expressed a desire to become part of teaching faculty of educational institutions in Taxila, to help save and promote the centuries old Gandhara stone art tradition from dying out.

\subsection{Indigenous Antiquing Treatments applied on Sculptures}

\subsubsection{Chemical Treatment}

Some unknown chemical mixtures are also used to give a piece an antique look. The names of chemicals were not disclosed by Khan, as a precaution to his unique technique, but he did admit that it is done to give a piece an antique look to fetch the maximum price.

\subsubsection{Using Caustic Soda}

This was also reported used in various finishing phases for giving a piece a desired look. However, caustic soda effects on a stone sculpture were not detailed by Sahil.

\subsubsection{Tezab or Acid Treatment}

Acid is also applied on pieces to create the desired antique and old effect. The antique finish is applied on sculptures by the same artisans who are working on other parts of a piece.

\subsubsection{Heating Method}

Some pieces are heated before marketing to create an ancient look, but it was not explained how it is achieved, Sahil and his workshop team was very reluctant to give tricks of the trade in the hands of a researcher. I noticed earthen stoves in the workshop courtyard, see Figure 15. The courtyard was distributed in small compartments for different artisans working on different pieces. It was hard to figure out how and when they apply heating on a sculpture and for what effect? but it did become apparent that fire and heating is used for creating some effects at some stage.

\subsubsection{Burying in Mud}

Burying sculptures in mud for some time to show age on a piece to create an antique look is also one of the most common methods applied. The traces of dirt and mud on a piece make it look like a genuine excavated piece.

Sahil told the six clients who buy most of his sculptures sometimes do not ask for antiquing treatment and apply it themselves. This is indicative of the fact that the buyers of these sculptures are also experts in the trade of faking the antique look that fetch a much higher price.

\subsection{Detection of Stone Antiquities}

According to Sahil Khan there is no way to detect the age of a stone artifact. The only way the antiquities department and the clients try to detect the age of a sculpture in their laboratory is through heating system. That too is not a foolproof technique.

In the laboratory they try to check when the piece was heated in making. When they tell us your piece was recently heated, we say yes, because to detach the sculpture we had to heat it from the back. 


\subsection{Stone Types most Frequently used in Sculpture Making}

4.13.1 Green schist stone from Swat, found so far only in Malakand mountains (most expensive). Also, mentioned by Aman in her study (Aman, 2004). See Figure 8 for green schist stone.

4.13.2 Gandhara Stone (grayish black) also brought from Swat, see Figure 9.

\subsubsection{Margalla Stone}

Found in Margalla Hills on limited scale. It is used in very small quantity by sculptors, due to its limited availability.

The above mentioned are the only three types of stones primarily used by Sahil Khan for his sculptures. He told there are no local stones used for making particularly the sculptures of Buddha.

\subsubsection{Sand Stone for Mathura Sculptures}

Mathura Stone, according to Sahil Khan is very hard red color stone, also called Agra Stone and Hindu Shahi, in reference to its link with India, Mathura sculpture is scripture-based as compared to Buddhist sculpture. In 1990s Sahil khan used to buy this stone from Lahore for Rs 40 per $\mathrm{kg}$. So it is much more expensive to get Mathura stone and make sculptures, because the stone is so hard to cut and carve, and is so much more expensive. Hence, the demand is very low, but he does make them on order if his clients so desire.

\subsubsection{Serpentine or Soap Stone, also found in Swat and Gilgit-Baltistan}

This stone is also used very infrequently in sculpture making.

\subsubsection{Khajoor (date) Stone}

It resembles the terra-cotta (Note 5) or earthen color mati-numa-pathar as per description of the respondents. Also used on a very small scale.

\subsubsection{Serikot Stone}

It is a soft layered stone found in Serikot area near Taxila and used in making grave stones and some other sculptures but not Buddha statues, See Figure 16 showing Serikot Stone. Few people use stone from Serikot (near Taxila, repeat, take out) to make grave stones, which are very famous from Serikot. (Note 6)

\subsection{Marketing Challenges}

Local people do not have any access to dealers even if they make any pieces. Sahil Khan said many people come to him and he finds them a buyer for their pieces. Locally this art is not promoted with the fear of reaction of the local populace as well as religious clerics. Sahil Khan said he keeps changing the venue of his workshop fearing an attack. Museum authorities do not provide any marketing outlet, instead they suppress any marketing effort initiated by local traders themselves to earn a living.

\subsubsection{Prices of Sculptures}

The price is generally negotiated according to the customer's pocket. Wealthy customers are asked to pay more as compared to an average occasional buyer.

But the general rate, as mentioned earlier, is rupees twenty five to thirty thousand per foot and that way roughly a 3-feet Buddha sculpture is worth Rs. 100000 (one lakh) minimum. Way beyond the reach of many local Gandhara art lovers. Also, people in majority of the cases do not like to adorn their spaces with statues, following Islamic ideology.

\section{Threats to the profession}

Four major threats to sculpture making business are:

\subsection{Regulatory Bodies}

The department of Archaeology and Museums as the major regulatory body does not help artisans to promote their skill through training, providing marketing outlets, or unrestricted local selling. They raid and try to prohibit any activity related to production of replicas, especially genuine stone statues, as mentioned earlier. Customs department is a big hurdle in transportation of replicas, they inspect and confiscate any pieces taken for selling by the local dealers. Due to this fear local dealers like Sahil Khan have to use other secret sources and marketing channels. Working through the middlemen on much lower prices. 


\subsection{Local Clergy}

Local religious leaders and other people having a religious mindset also greatly condemn idol making and selling for a living in the area. The workshops are under constant threat of a raid by both the regulatory authorities as well as clergy and locals populace. Which results in low production and meager incomes for those involved. Moving workshops from place to place to hide from the wrath of various opposition groups locally, as in the case of Sahil's newly moved workshop in a narrow alley of village Pathrian, See Figure 4.

He said, local clergy keeps chasing me but I tell them that they should find me an alternate job where I could earn the equal amount of money, and then they keep quiet and let me do my work. He confessed that he finds it very difficult to always work under pressure to earn a living through sculpture making.

\subsection{Growing Religious Extremism}

Lately a growing religious extremism in the region is also an important factor in reducing the sculpture making and marketing business. After the 9/11 incidence tourist traffic has reduced to a great extent and foreigners do not come to visit so often. The sales have drastically dropped after 9/11 incident and more so following increasing terrorism incidents especially after 2007, as per local sellers.

\subsection{Dearth of Master Sculptors}

According to informants master stone sculptors of Taxila are well known for their work. People from far flung areas came to them since old times to order custom made pieces and also provided them schist stone to get their pieces made. The labor of a stone sculptor was rupees fifty a day [few years ago] depending upon the height of the statue [Buddha] measured in feet. A master sculptor could take any amount of days or months to complete a genuine stone Buddha sculpture.

In June of 2010 during the visit to interview the master sculptor, Sahil Khan, in village Pathrian, I was told that currently the rate for carving a statue is Rs 25000 to 30000 a foot. And a 3-feet statue costs rupees 100000 and more depending upon which master sculptor is making the piece. According to him, his permanent clients who are in this business can easily differentiate between a sculpture made by a lay person and a master sculptor, and they are willing to then pay the price for a piece accordingly. Each piece is custom made according to the taste and demands of his clients, and priced accordingly. A good piece fetches the highest price and an average piece an average price. The sculptors also do their best to get good price for a piece, as it is a laborious job.

Unfortunately over the years, as per Sahil Khan, not many older generation master sculptors are alive, including Sahil's own ustad (teacher). (Note 7) According to Sahil in his village of about 4000 people (village Pathrian) there are only ten to fifteen people who are master sculptors. Cheap replicas of stucco and terracotta, using mold-based technique are also made by only twenty to twenty five households in the village.

Buddha sculptures have some local market, and Sahil identified one of the famous industrialist family of Pakistan who are his regular clients but most of them are made for an international market, taken by middle men and the smuggling mafia involved in this business.

This has caused a big loss to this art form in the recent past. If not preserved even now by promoting the left behind few trained sculptors like Sahil Khan, this centuries-old stone art may die entirely at the hands of increasing religious extremism and shrinking tourism and marketing opportunities of Gandhara Sculpture within and outside Pakistan.

\section{What Needs to be Done: Recommendations by the Master Sculptor, Sahil Khan}

Sahil Khan, recommended few measures based on his 25 years of sculpture making experience to preserve and promote the Gandharan sculptural art in Taxila:

6.1 He strongly recommended that Government should consider making another Museum to display only contemporary Gandhara sculptures of genuine stones. Because the antique mjasma [e] (statues) were made only in black Gandhara stone and green schist stone, artisans in Taxila also make Buddha sculptures in those two stones. These genuine reproductions can be a big source of income for the government and will promote master sculptors, artisans and the dying art.

6.2 The relatively inexpensive replicas, using molding technique, sold for few hundred rupees, as compared to genuine stone statues worth thousands of rupees, have also spoiled the real stone sculpture business, and according to him they should not be allowed to make cheap replicas (for details see Malik and Ihsan, 2010) 
6.3 He proposed setting up art galleries locally for showcasing and selling the local stone arts, which are numerous, and can be a great source of income through attracting tourists. He does not have much hope from present Museum in Taxila or authorities running it.

6.4 Sahil Khan proposed that a training institute should be established to conserve and revive the dying Gandhara art and especially making of genuine stone "sculptures of Buddha" that fetch big price in the international market, especially Buddhist countries.

Those employed in making cheap replicas should also be employed by the government in the training institute that Sahil Khan is proposing on salary or daily wages, to create a living for them, which is not the case at present. There exists widespread poverty and joblessness among producers of cheap replicas in and around various archaeological sites of Taxila Valley

6.5 He said, department of Archaeology and Museum should cultivate good linkages with local stone artists instead of being in constant strife with them. A good working relationship between the two is immensely important to promote this dying art. At present a constant strife between them is having negative influence on the growth of Buddhist sculptural art in Taxila.

\section{Conclusion}

The Gandhara stone art produced on a limited scale at the hands of legendry sculptors of historic Taxila is a dying art that needs to be preserved and promoted for its survival. The growing religious extremism and a shrinking market of Buddhist stone art from Taxila need patronage by both the concerned government authorities and the international community of museums and Buddhist countries. This could be achieved by establishing training institutes and art galleries for showcasing and marketing contemporary Buddhist stone art of Taxila. The role of Taxila Museum can be further enhanced by establishing a Museum Shop that carries finest specimens of Buddhist sculptural art produced locally, to promote its marketing instead of putting a ban on selling sculptures. The Antiquities Laws of 1975 also need amendments to accommodate marketing of reproduction [s] of the ancient Buddhist stone art and issue licenses to producers for the legal coverage.

To avoid smuggling of genuine antique pieces, the new sculptures could be issued a certificate of a genuine reproduction by the Museum authorities or the art galleries, like generally practiced in the Western countries. In the face of dried up pilgrimage and tourism due to security reasons, there is a dire need to conserve whatever is left behind. Both in terms of marketing the Buddhist stone statues and even more importantly, to protect and promote the skills of the few remaining master sculptors; the makers of this ancient art form. Their centuries old skills need to be transmitted to the younger generation of sculptors and stone carvers to save the future of this exquisite ancient Buddhist sculptural art.

They need immediate patronage from national as well as international authorities. Buddhist countries can play a pivotal role in this conservation effort by helping in establishing training institutes for training of younger generation of local sculptors and by marketing their art in their respective countries.

\section{References}

Ahmed, Q. I. (2010, August 15). Gandhara Art: Visions of Divinity. Dawn Islamabad.

Aman, N. (2004). The Residue of Gandhara Civilization with Respect to Time Dimension. (Unpublished master's thesis). PMAS University of Arid of Agriculture, Rawalpindi.

Anonymous. (n.d.). Wikipedia. [Online] Available: http://en.wikipedia.org/wiki/Gandhara (March 25, 2011)

Ansari, M. (2002). Plundering Afghanistan: A booming antiquities trade strips the country of its cultural heritage. Archaeology, 55(2). [Online] Available: http://www.archaeology.org/0203/abstracts/ specialreport.html (April 4, 2011)

Antiquities Act 1975. (1992). The Department of Archaeology and Museums. Ministry of Culture and Tourism. Pak.

Antiquities Act, Pakistan. (1975). Dept. of Archaeology and Museums, Ministry of Culture and Tourism, Karachi. (1992).

Antiquities Export Control Act, Pakistan. §3. (1947). [Online] Available: http://webcache. googleusercontent.com/search?q=cache:http://www.inamlawdirectory.com/antiquities-export-control-act-1947-c 1 (March 26, 2011)

Correspondent. (2010, August 4). South Korea to Support Gandhara University Project. Dawn Islamabad. 
Customs Act, Pakistan. (1969). AOnline] Available: http://www.fbr.gov.pk/newcu/CustomsAct/2009-2010/CustomsACt1969June302009.pdf (March 26, 2011)

Iqbal, A. (2010, March 21). Interview of Master Sculptor, Mr. Ilyas Khan. Dawn Islamabad.

Kenoyer, J.M. (2002). Challenges in Pakistan: Efforts to combat a Taliban mentality. Archaeology.55 (2), abstracts.

Khalid, S. (2011, January 3). Archaeologists to seek world support to save scripts from defacing. NEWS Islamabad.

Khan, M. A. \& Mahmood-ul-Hasan. (2003). Buddhism and its Influence on the Cultural Heritage of Pakistan with Special Emphasis on Gandhara. Journal of Asian Civilizations, XXXI (1)55-59.

Malik, S.B. \& Farhan Ihsan. (2010). The Production and Marketing of Replicas of Buddhist Stone Art of Gandhara in Taxila. Journal of Asian Civilizations, 33(1)116-132.

Marshall, S. J. (1960). The Buddhist Art of Gandhara: The Story of the Early School its Birth, Growth and Decline. Cambridge, Published for the department of Archaeology in Pakistan: At the University Press.

Muhammad, W. K. (1964-1965). Inception of Gandhara Sculpture. East and West, 15(1-2)53-61.

Nadiem, I. H. (2008). Buddhist Gandhara Treasures: Taxila Museum. Sang-e-Meel Publication, Lahore, Pakistan.

Rhi, Juhyung. (2008). Identifying Several Visual Types in Gandharan Buddha Images. The journal of Archives of Asian Art. [Online] Available: http://muse.jhu.edu/journals/archives_of_asian_art/vo58/58.rhi.html (March 25, 2011)

Shahid, J. (2011, March 20). Some People are Just Lucky. Dawn Islamabad.

Tarakzai, Sajjad. (2009). Taliban Suffocate Pakistan-Buddhist Heritage. Wisdom Quarterly: American Buddhist Journal. [Online]

Available:

http://wisdomqusarterly.blogspot.com/2009/11/taliban-suffocate-pakistans-buddhist.html (March 25, 2011)

UNESCO World Heritage Repots (12). (2004). The State of the World Heritage in the Asia-Pacific Region (2003). The UNESCO World Heritage Center France, p.3.

Zaman, Mahmood. (2011). State Vandalism of History in Pakistan. Vanguard Books. Lahore, Karachi, Islamabad, Pakistan.

\section{Notes}

Note 1. For the replicas of Buddhist stone art produced by using molding techniques, see forthcoming "The Production and Marketing of Replicas of Buddhist Stone Art of Gandhara in Taxila," (Malik and Ihsan, 2010).

Note 2. There was a clear reluctance to share any information regarding his earnings from this business of selling sculptures. He said all these statues of Buddha are purchased by only six clients, who he has contacts with, and who sell them outside Pakistan on much higher prices. They are the one benefiting from this business not he or his fellow workers, he complained.

Note 3. For replicas using molding technique, in stucco and terracotta, see Malik and Ihsan, Journal of Asian Civilizations, Vol. 33 (1) 116-132, July 2010 Issue.

Note 4. His two appeals to the authorities to save Buddhist Gandhara Art, appeared in Daily Dawn, Islamabad in March 2010, and another on $14^{\text {th }}$. March 2011, where he asked to help save him from his ongoing fight with gangrene and offered to help teach stone art to the new generation to save it from extinction.

Note 5. Italian: terra, earth (from Latin) + cotta, baked, cooked (from Latin), (Microsoft Bookshelf, 2000).

Note 6. Graves in Serikot also have beautiful symbolism engraved for men and women using serikot stone, as also seen on Chaukundi graves, in the Sindh Province, near Karaci City.

Note 7. Ghulam Muhammad (pseudonym) who was taken to the US by a famous industrial family of Pakistan for their own use) has been sick for years with stroke and died recently. 


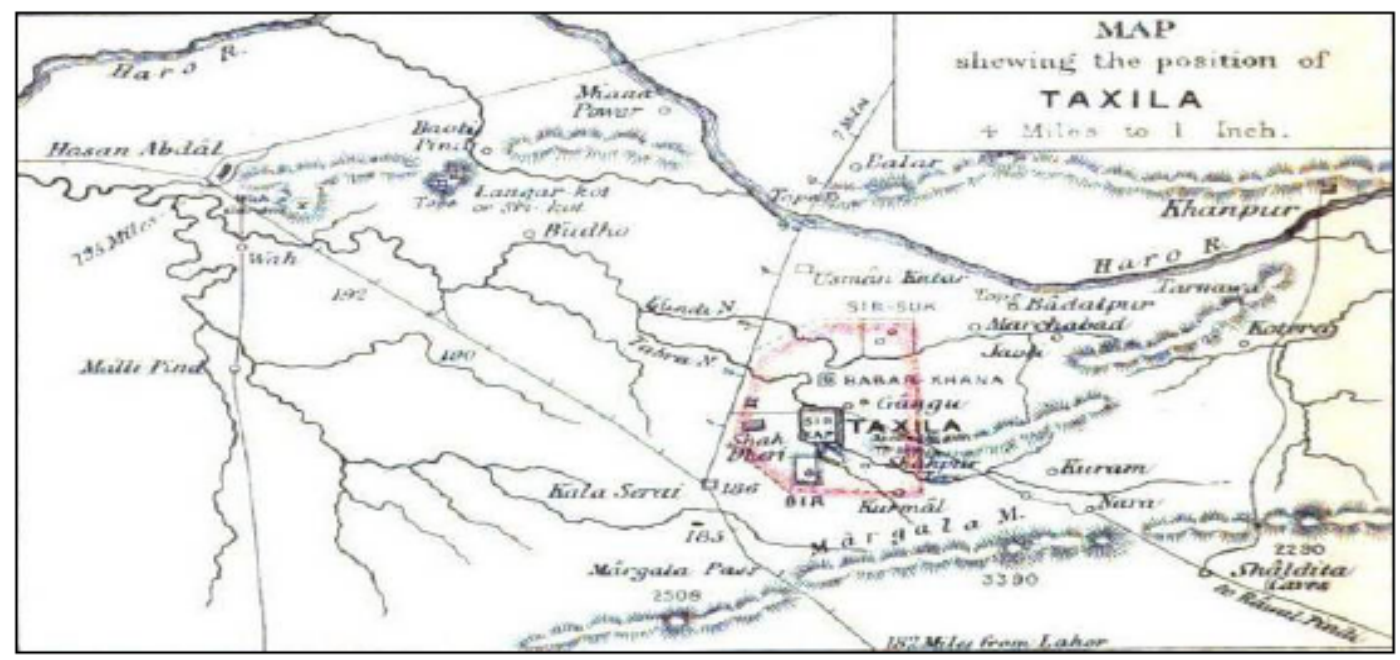

Figure 1. Map of Taxila Valley with archaeological site Sirkap shown in a box

(This map has been taken from the URL: http://3.bp.blogspot.com/_kv9vfYe_bqI/TNY15vv3hEI/AAAAAAAAAIQ/u1GaSixpfo/s1600/map+of+takxila.j pg)

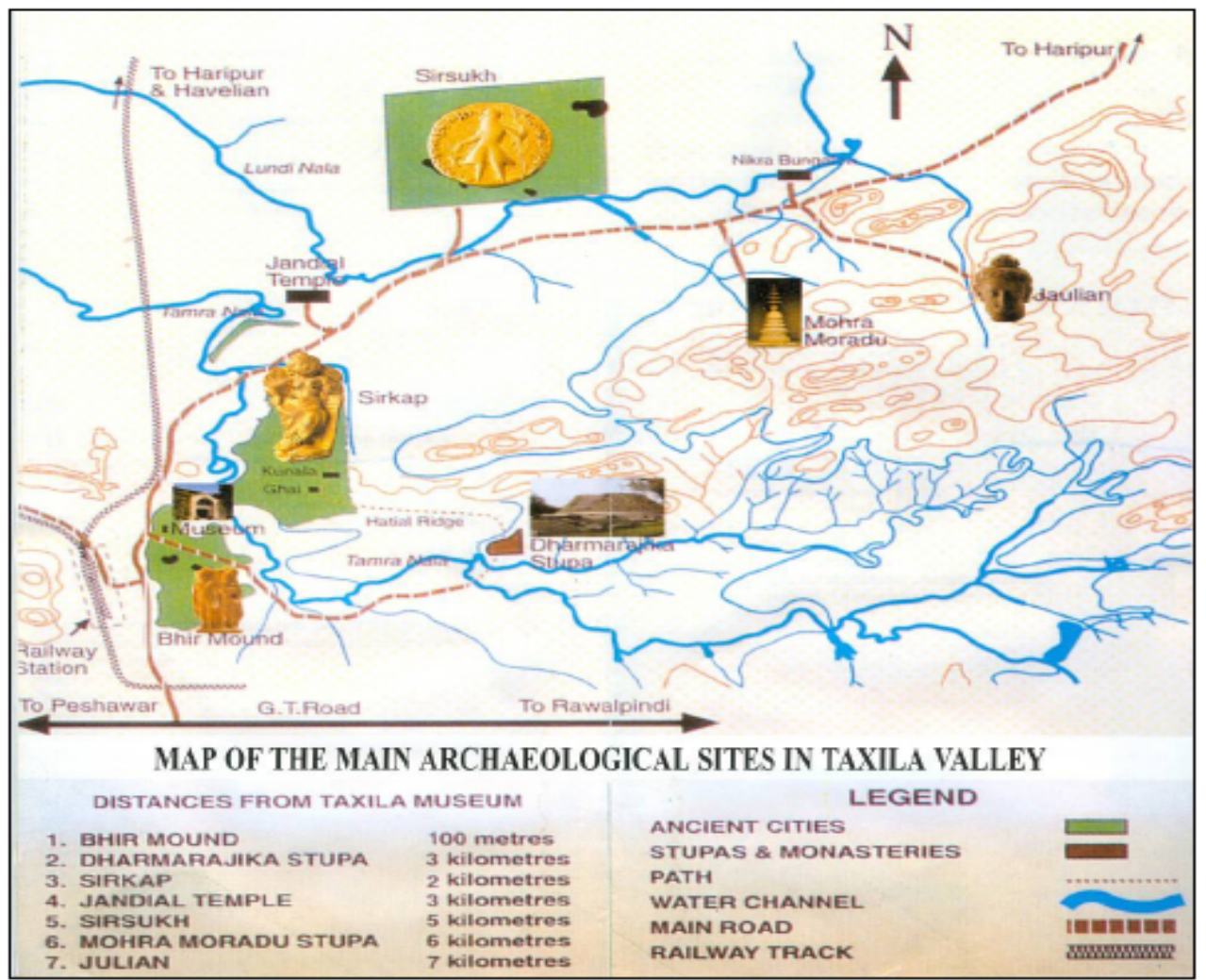

Figure 2. Map showing archaeological sites of Taxila

(This map has been taken from The Museum Guide. The Archaeological Museum Taxila, Department of Archaeology \& Museums, Government of Pakistan.) 


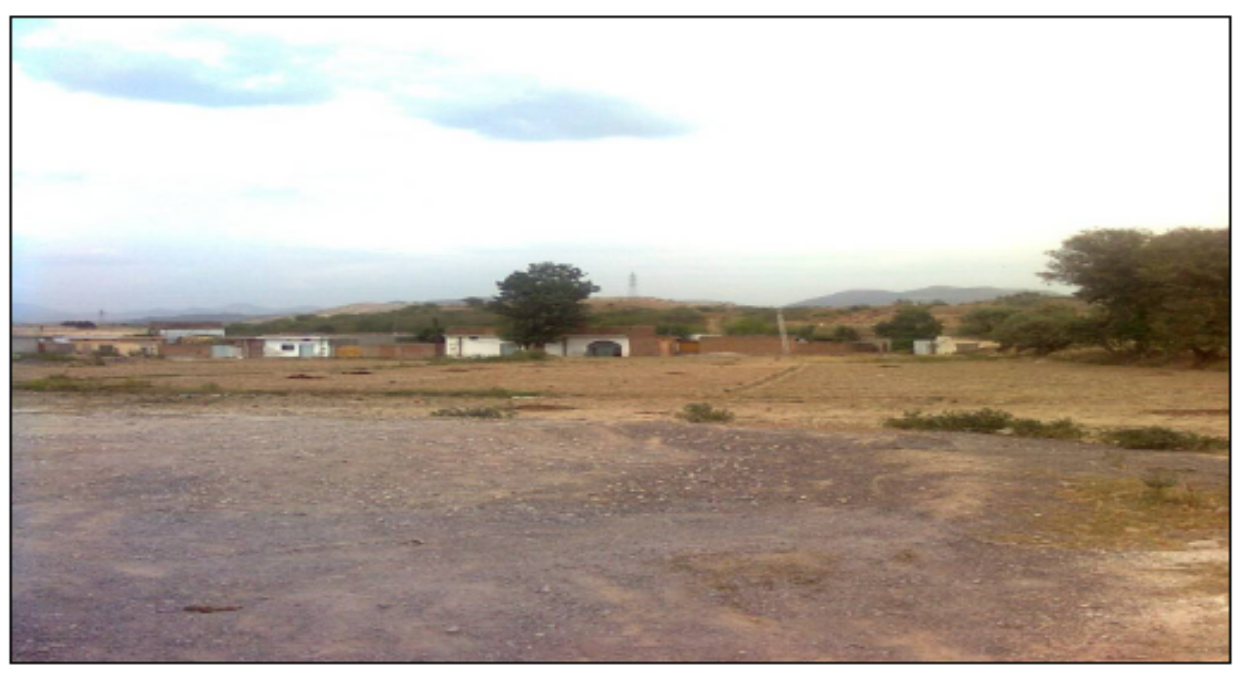

Figure 3. Village Pathrian in Taxila

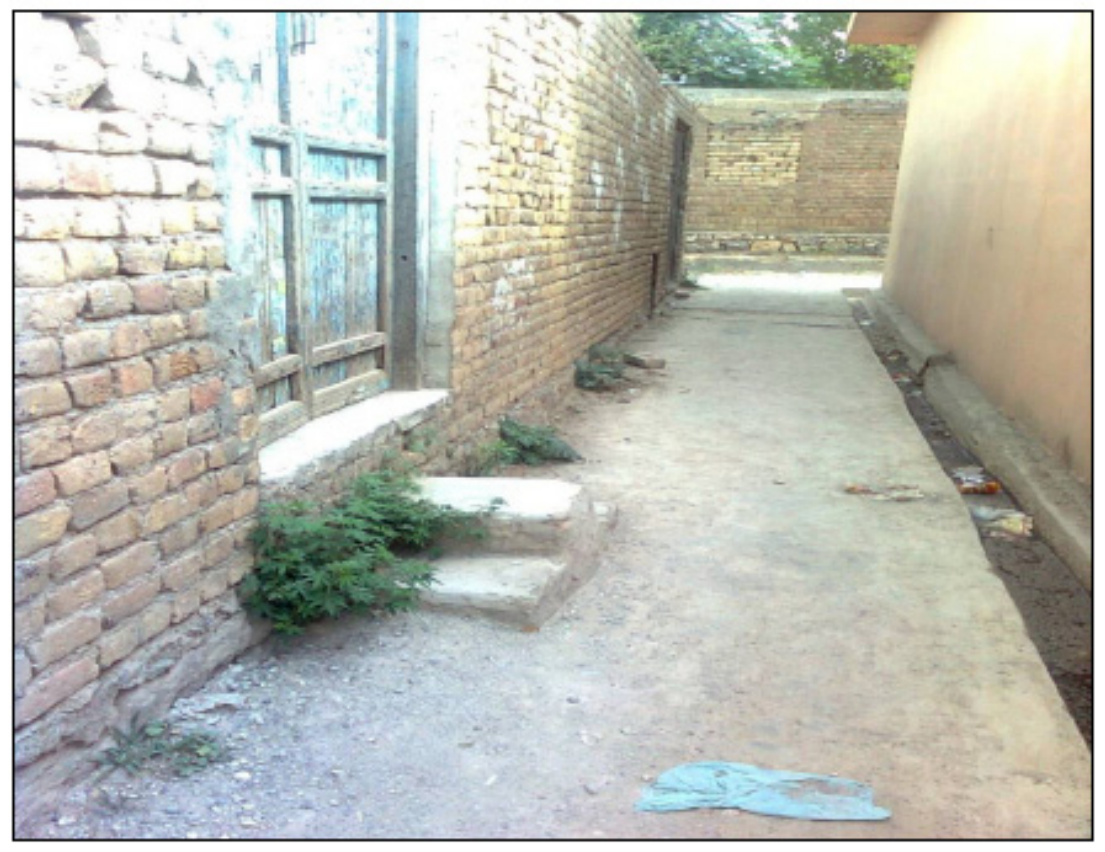

Figure 4. Narrow alley leading to the door of Sahil's secret workshop 


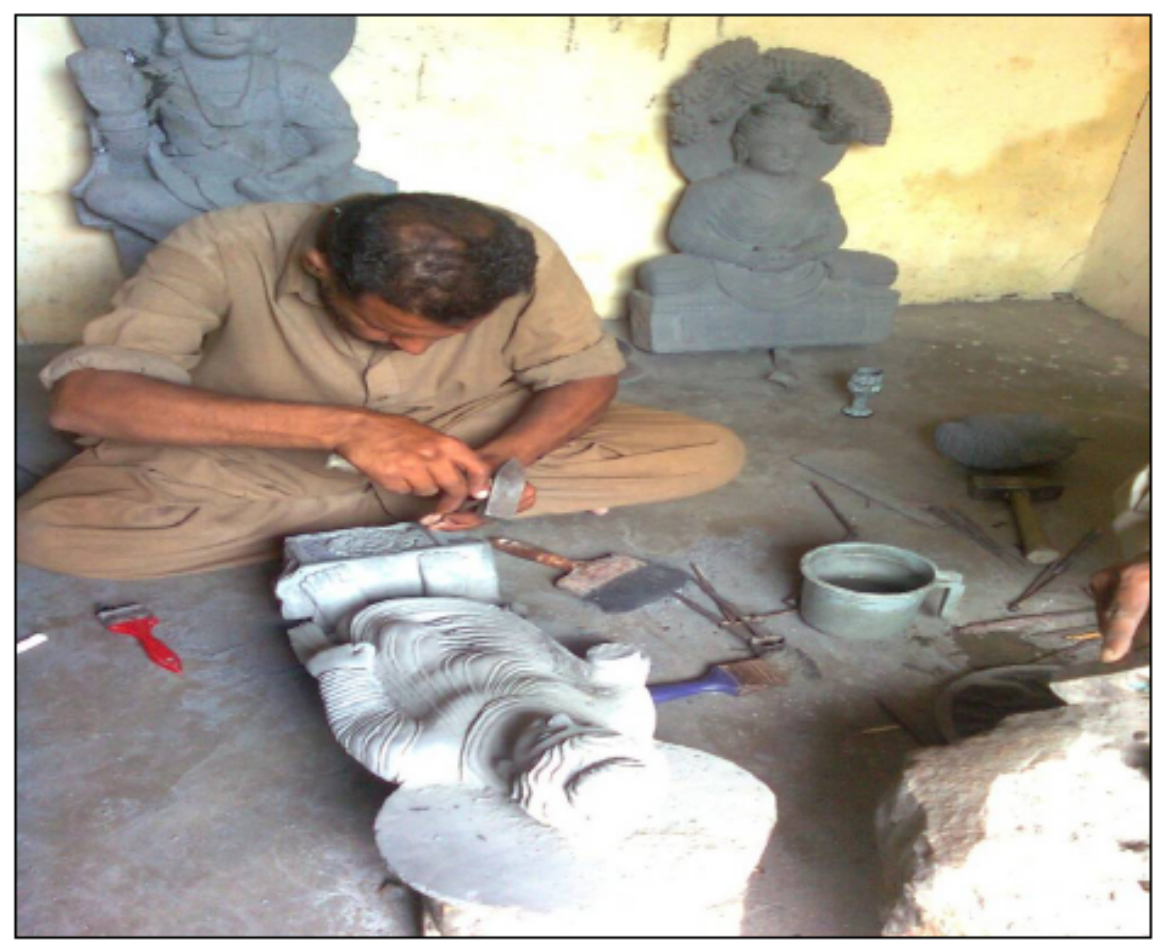

Figure 5. Artisans at work in the workshop

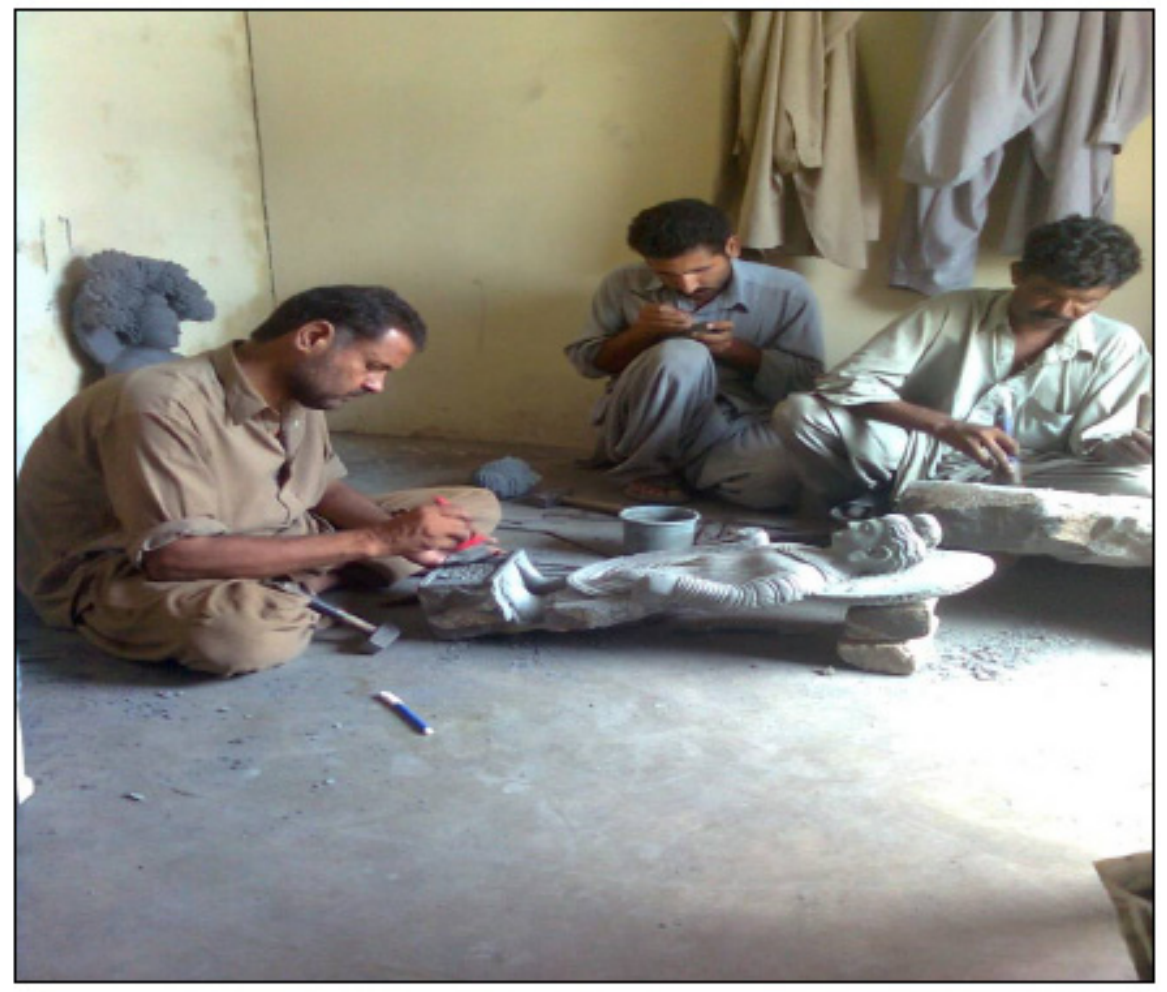

Figure 6. A typical carving and finishing session in the workshop 


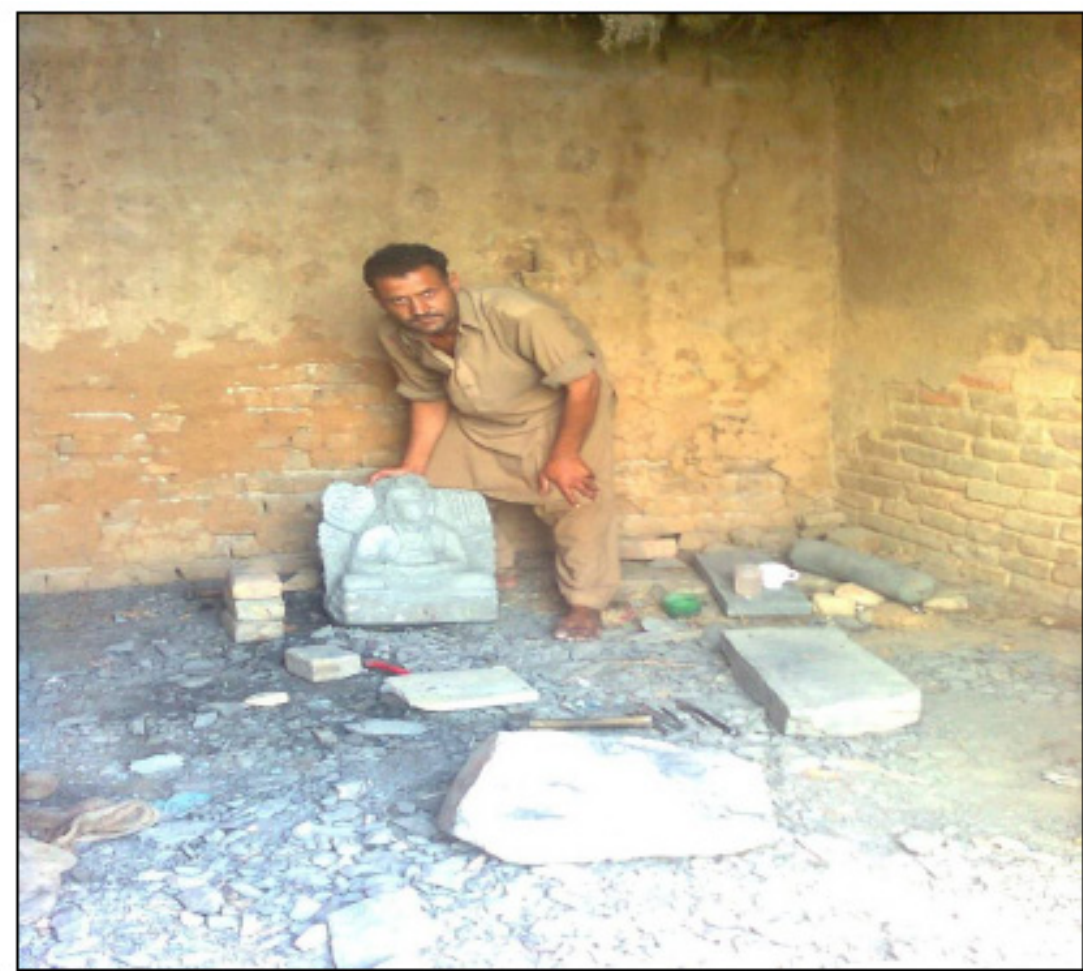

Figure 7. A green schist seated Buddha sculpture in the courtyard of the workshop placed for jewelry making

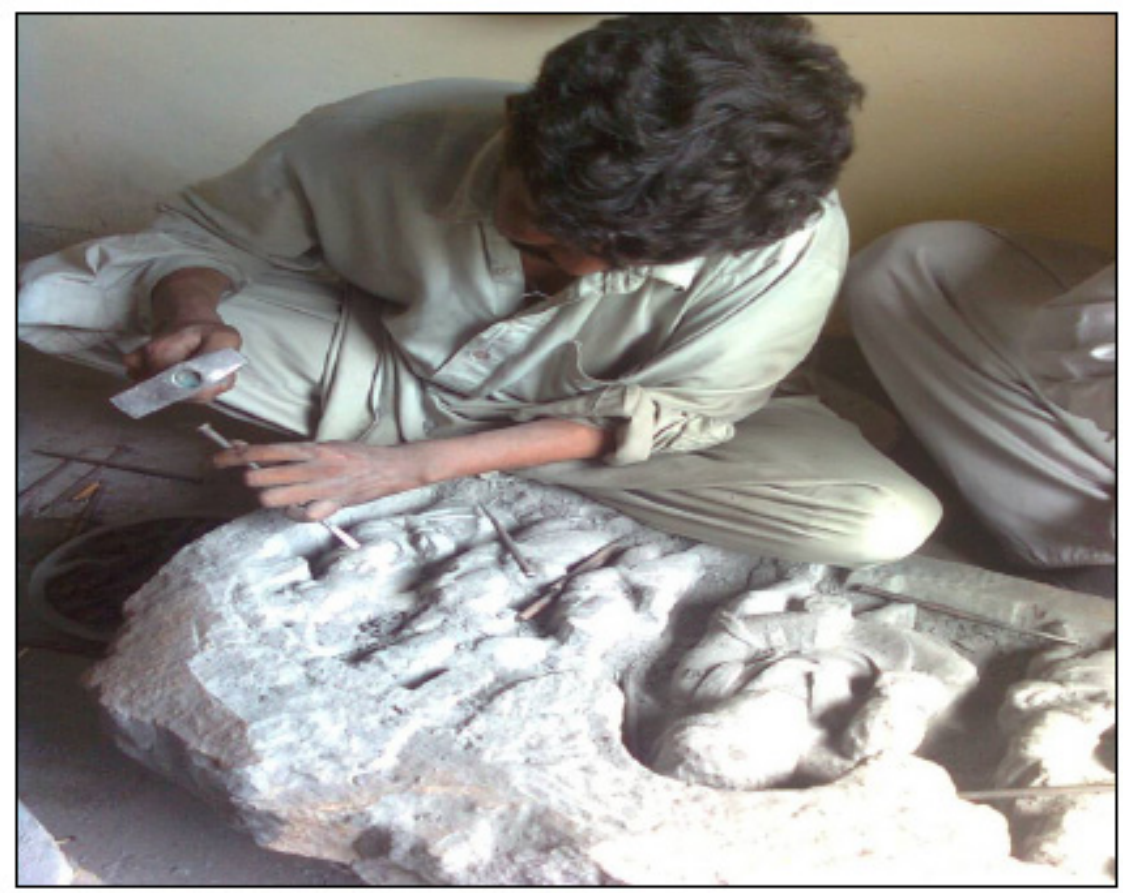

Figure 8. A green schist relief showing the thickness of the stone slabs required for carving big pieces 


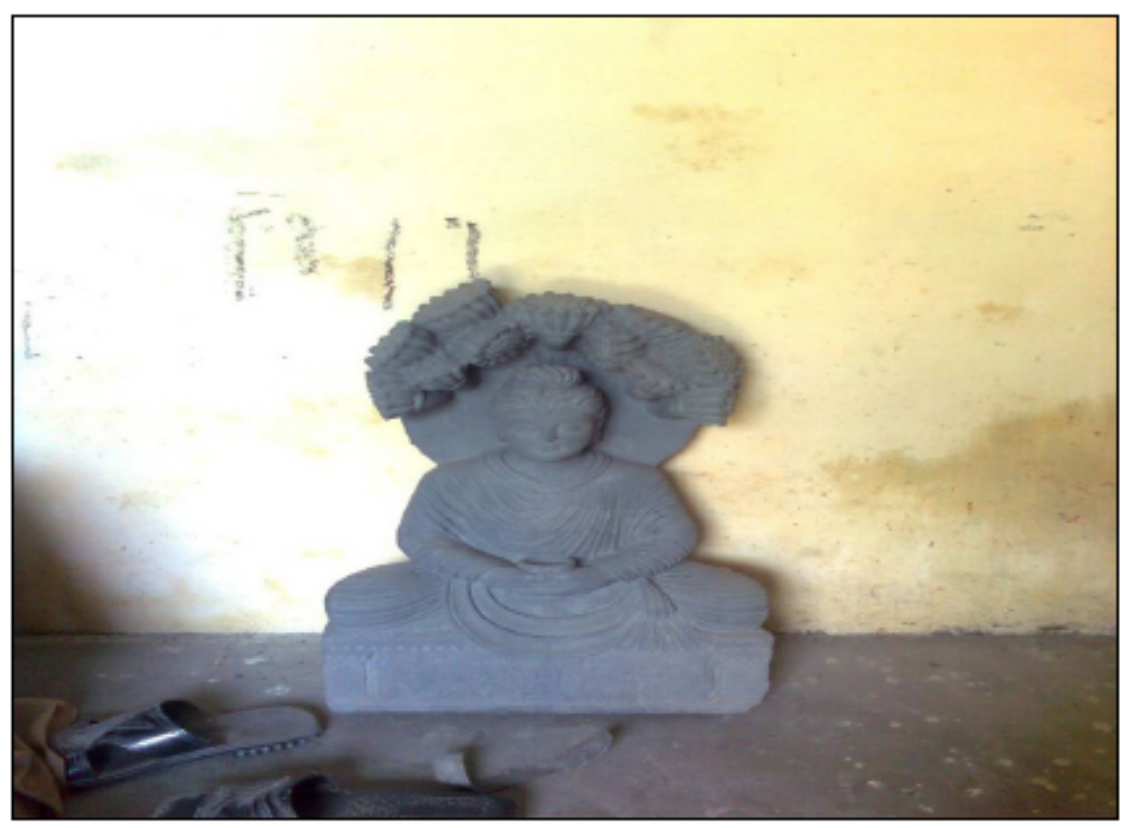

Figure 9. A finished sculpture of Buddha in black Gandhara Stone ready for sale in the workshop

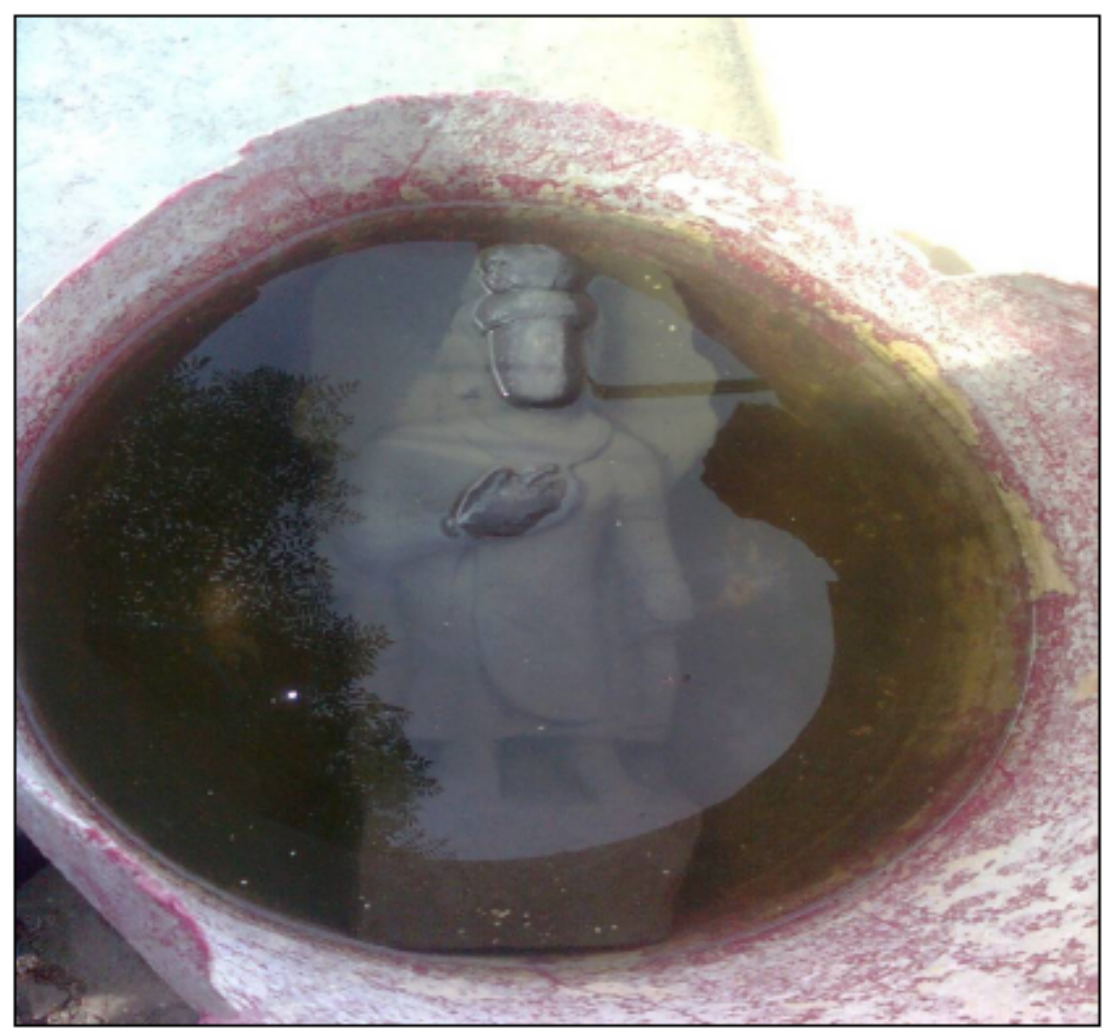

Figure 10. An unfinished Buddha sculpture soaked in water to soften it for final decorating and finishing 


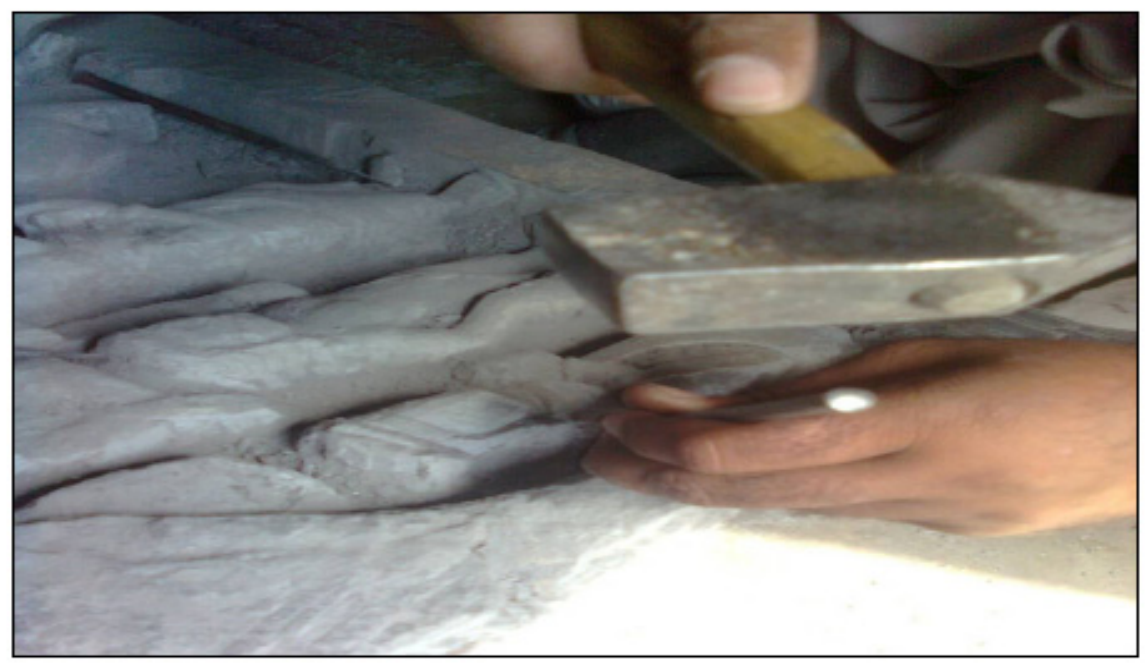

Figure 11. A close up of a relief and hand tools used for carving

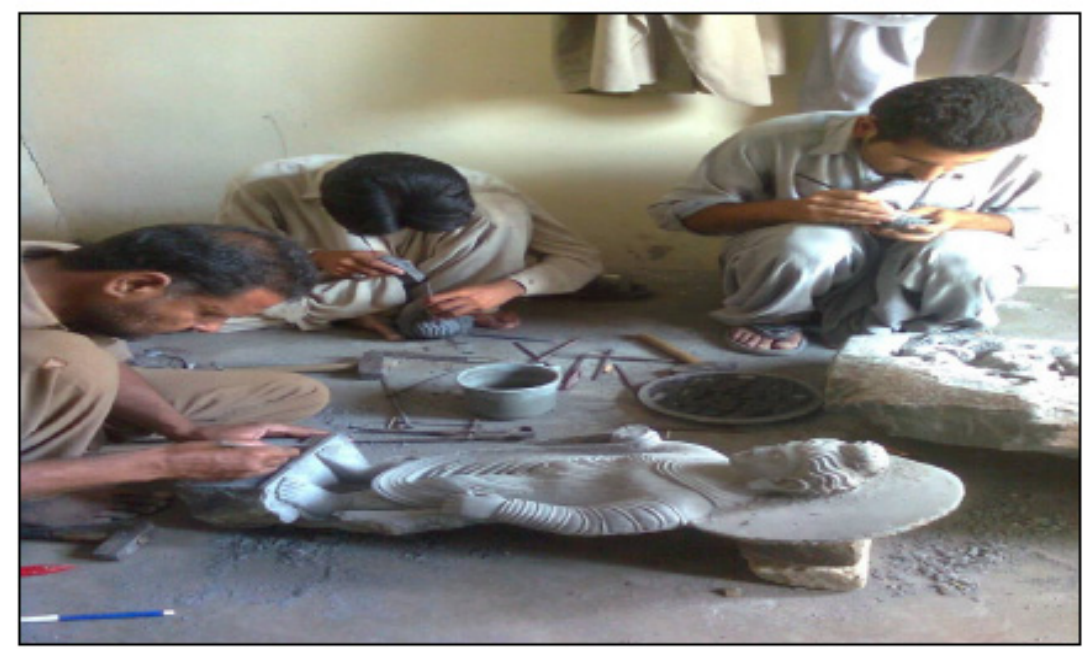

Figure 12. The typical workshop scene with three artisans working on three different pieces with their hand tools scattered on the floor

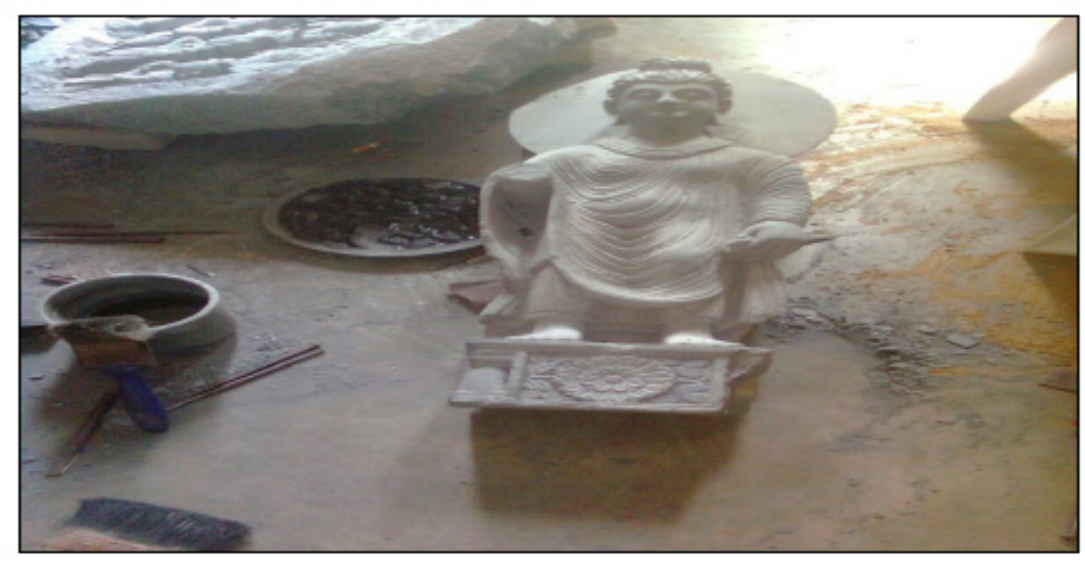

Figure 13. Various tools and materials used by the carvers 


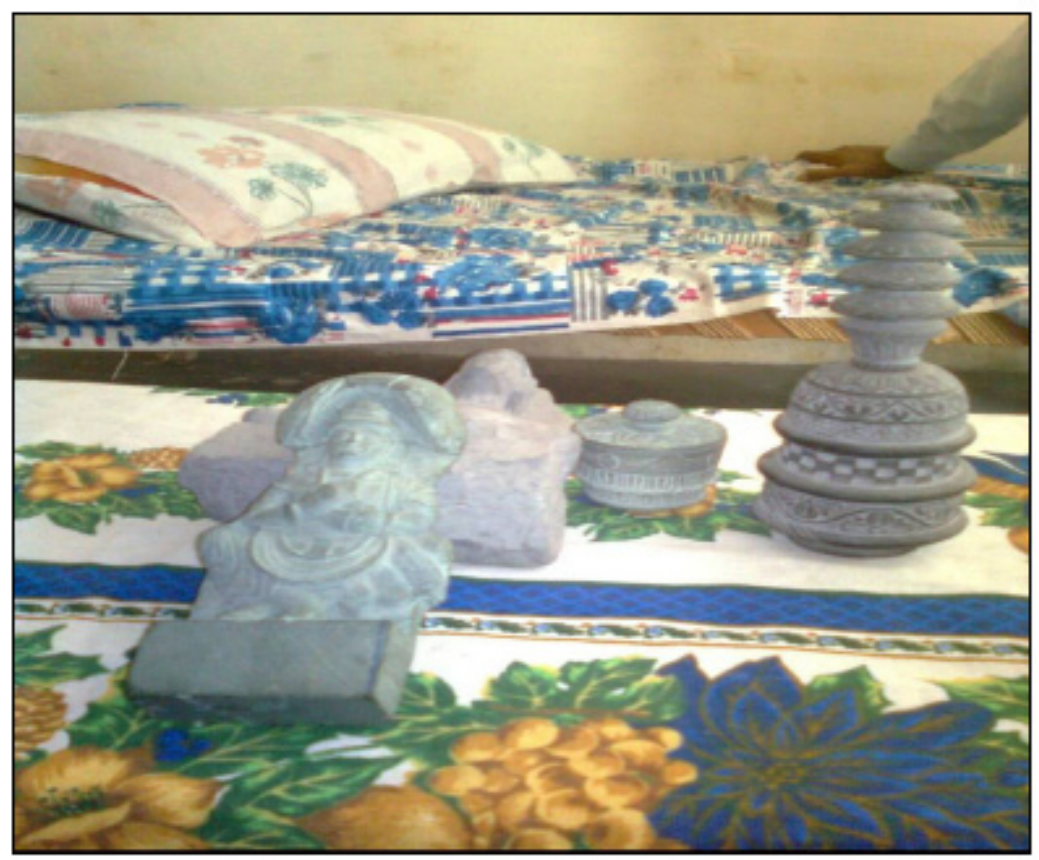

Figure 14. The genuine green schist stone replica of Buddha sold at rupees 10,000 in Sahil's workshop, can be easily bought in molded replica-form for rupees one to two hundred from sellers on any archaeological site in Taxila

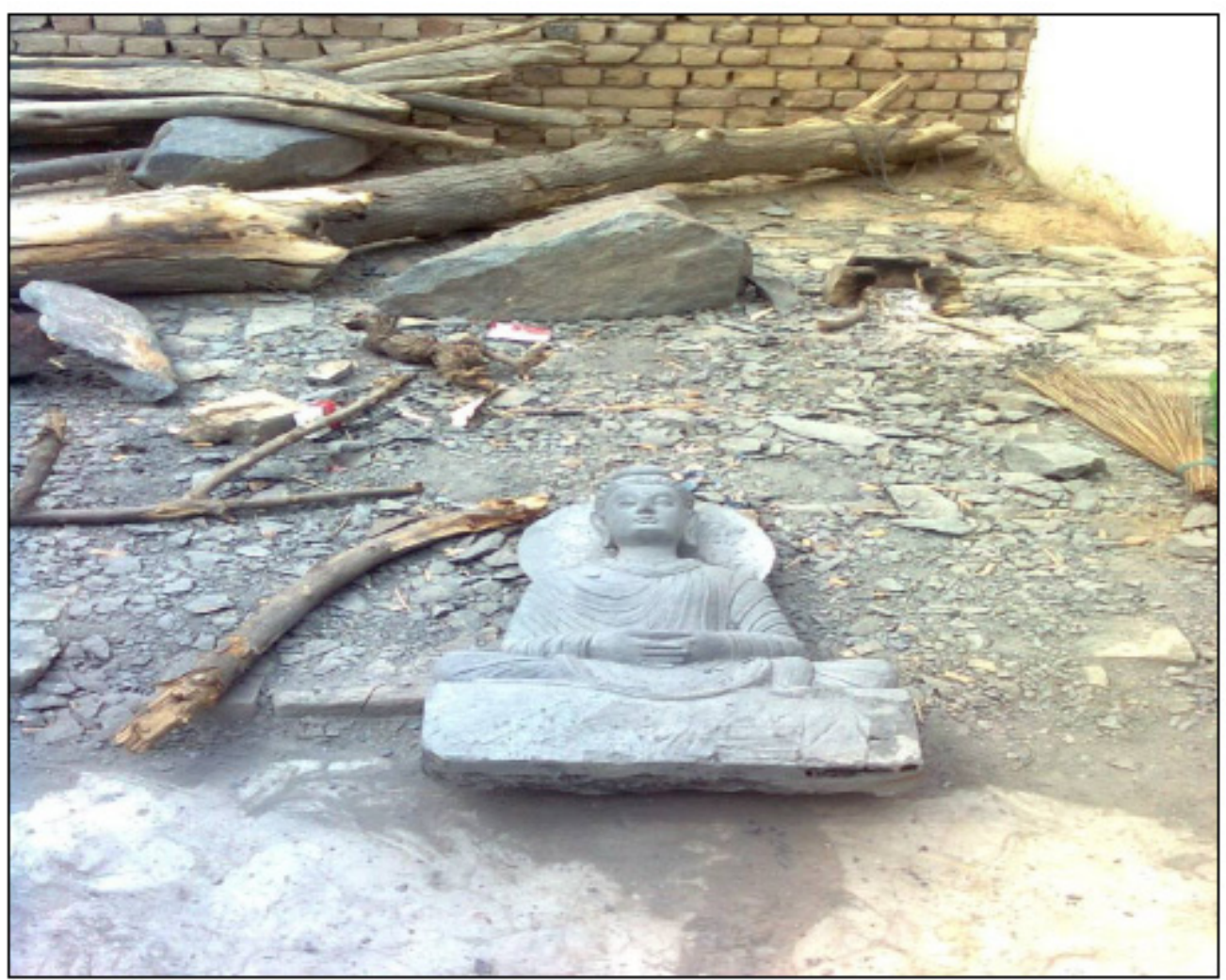

Figure 15. Workshop courtyard used for applying various antiquing finishes on sculptures 


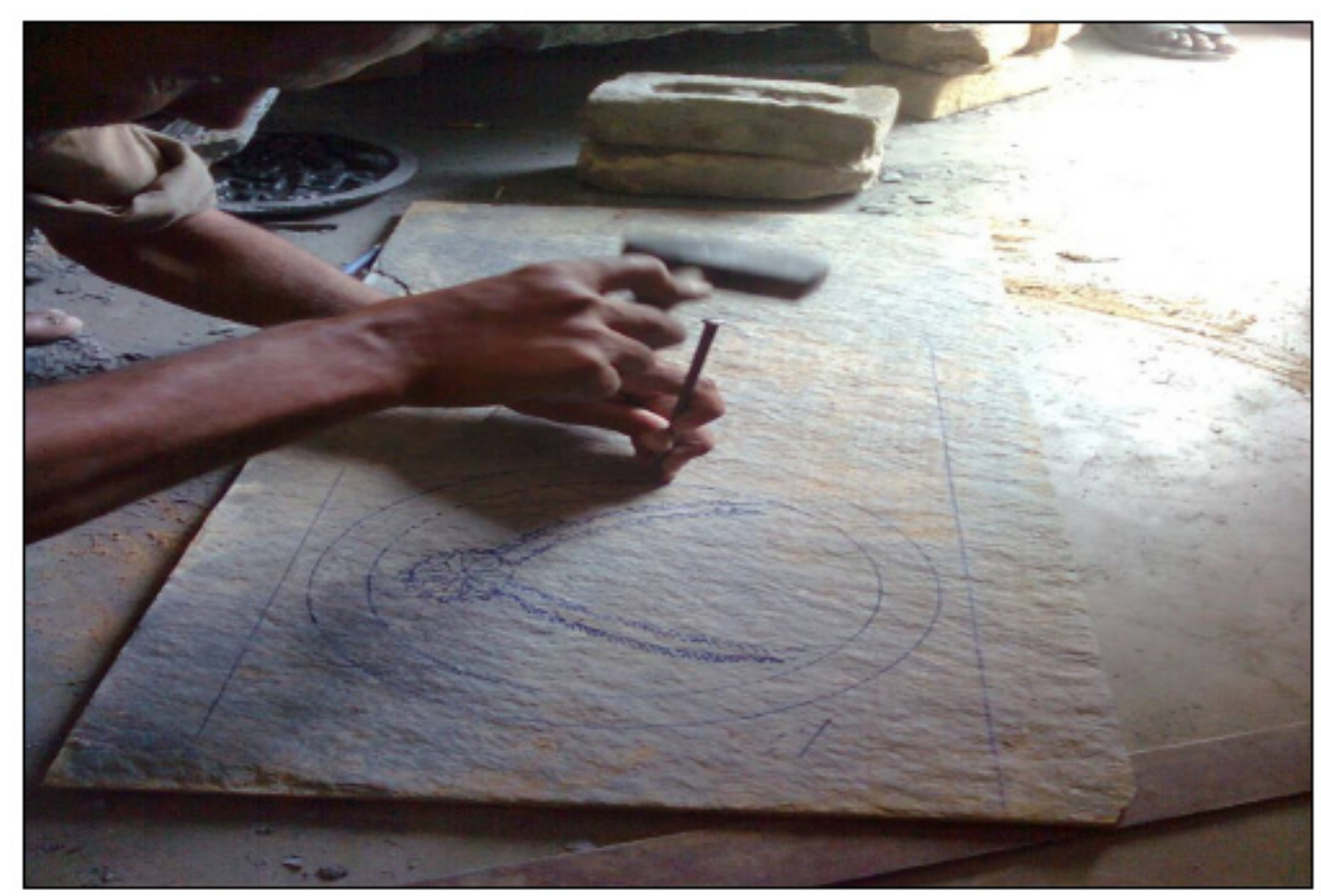

Figure 16. A sculptor tracing jewelry on a Sirikot Stone slab to demonstrate 